\title{
PERLINDUNGAN HUKUM TERHADAP KONSUMEN MUSLIM DARI PRODUK PANGAN YANG TIDAK BERLABEL HALAL DALAM PERSPEKTIF HUKUM POSITIF YANG TERKAIT DI INDONESIA DAN DI KOREA
}

\author{
1. Ari Mariyana Angriyani \\ 2. Susilowati Suparto \\ Faculty of Law, Padjajaran University \\ mariyanaarie18@gmail.com / susilowati.suparto@unpad.ac.id \\ Submitted: 2020-09-25; Reviewed: 2020-10-01; Accepted: 2020-11-20
}

\begin{abstract}
Halal Certificate is a written form of halal statement to show that the product itself has a halal status. The halal label serves as consumer protection so that the right of Muslim consumers to consume halal products is guaranteed. Indonesia as a country with a Muslim majority population maintains the halal value of a product, especially food. Lately, the number of products that have not been certified halal has made it difficult for Muslim consumers to distinguish between halal and non-halal products for consumption. The emergence of various foreign food products from various countries has become commonplace for society. However, in reality the products circulating in Indonesia are not guaranteed to be halal so that supervision is needed so that non-halal products cannot be circulated and consumed by the Indonesian Muslim community. The purpose of writing this journal is to explain legal protection efforts for Muslim consumers from food products that are not labeled halal in a positive legal perspective in Indonesia and in Korea. The method used refers to statutory regulations. The data obtained were analyzed qualitatively. Based on the research results, the regulations related to Halal products are still very minimal. Therefore, in the Korean trade regulation, it is stated that: "Acceptance of agency for commercial transactions", which means Korea gives freedom to every agent to carry out trade transactions including the halal labeling of their products. The form of consumer protection for Muslim consumers is halal certification.
\end{abstract}

Keywords: Consumer Protection; Halal Certificate; Muslim Consumers. 


\section{PENDAHULUAN}

Globalisasi, perdagagangan bebas dan Masyarakat Ekonomi Asia (MEA) dewasa ini berdampak meningkatnya peredaran produk makanan dan minuman baik lokal maupun impor di masyarakat. Produk makanan dan minuman yang beredar dimasyarakat belum tentu memberi rasa aman, nyaman, tenteram dan layak dikonsumsi oleh konsumen muslim, karena syariat Islam mewajibkan kepada umat Islam untuk mengkonsumsi makanan dan minuman yang halal sesuai syariat Islam. ${ }^{1}$ Munculnya berbagai produk makanan asing dari berbagai negara di mini market maupun super market telah menjadi hal yang lumrah bagi masyarakat. Meski globalisasi membawa banyak kemajuan di berbagai bidang, namun globalisasi juga membawa suatu nilai yang tidak selalu sesuai dengan nilai-nilai yang dianut oleh mayoritas masyarakat Indonesia, salah satunya adalah nilai tentang halal. Jumlah penduduk muslim di Indonesia saat ini diperkirakan mencapai angka $70 \%$ dari sekitar 250 juta jiwa total jumlah penduduk. ${ }^{2}$ Oleh karena itu, menjaga nilai halal menjadi salah satu prioritas mutlak. Tidak semua produk yang beredar di Indonesia terjamin kehalalannya, sehingga perlu pengawasan agar produk-produk yang tidak halal, tidak dapat beredar dan dikonsumsi masyarakat Muslim di Indonesia.

Terminologi "halal" dalam Kamus Besar Bahasa Indonesia (disebut dengan KBBI) bermakna "diizinkan". ${ }^{3}$ Halal merupakan istilah untuk menunjukan benda atau suatu tindakan dalam hukum islam. Istilah makanan halal digunakan untuk menunjuk makanan yang dilihat sebagai makanan yang boleh dimakan menurut hukum islam. Kebalikan dari kata halal adalah haram yang artinya terlarang atau mengandung zat yang terlarang dalam hukum islam. ${ }^{4}$ Untuk menghindari makanan haram, umat muslim mengkonsumsi produk makanan yang terjamin kehalalannya. Jaminan mengenai produk halal dilakukan sesuai dengan asas perlindungan, keadilan, kepastian hukum, akuntabilitas dan trasparansi, efektifitas dan efisiensi, serta profesionalitas. Jaminan penyelenggaraan produk halal bertujuan memberikan kenyamanan, keamanan, keselamatan, dan kepastian ketersediaan produk halal bagi masyarakat dalam mengkonsumsi dan menggunakan produk halal, serta meningkatkan nilai tambah bagi pelaku usaha untuk memproduksi dan menjual produk halal. ${ }^{5}$ Undang-Undang Nomor 33 Tahun 2014 tentang Jaminan Produk Halal (selanjutmya disebut UUJPH) memperkuat dan mengatur pelbagai regulasi halal yang selama ini tersebar di pelbagai peraturan perundang-undangan, di sisi lain UUJPH dapat disebut sebagai payung hukum (umbrella act) bagi pengaturan produk halal. Jaminan

${ }^{1}$ Syafrida, "Sertifikasi Halal pada Produk Makanan dan Minuman Memberi Perlindungan dan Kepastian Hukum Hak-Hak Konsumen Muslim”, Jurnal Hukum, Vol. 7 No. 2, 2016, hlm. 160.

2 Rudy Kurniawansyah, "Presentase Kaum Muslim di Indonesia Alami Penurunan", https://mediaindonesia.com/read/detail/59042-kaum-muslim-di-indonesia-tinggal-70-persen. Diakses pada 10 Maret 2020, Pukul 16.08 WIB.

3 Anonim, Kamus Bahasa Indonesia, Departemen Pendidikan Nasional, Jakarta: Pusat Bahasa, 2018, hlm 101.

${ }^{4}$ Musyfikah Ilyas, "Sertifikasi dan Labelisasi Produk Halal Prespektif Maslahat”, Jurnal Al-Qadau, Vol. 4, No. 2, 2017, hlm. 362.

${ }^{5}$ Lihat Penjelasan atas Undang-Undang Republik Indonesia Nomor 33 Tahun 2014 tentang Produk Jaminan Halal. 
Produk Halal (selanjutnya disebut JPH) dalam undang-undang ini mencakup pelbagai aspek tidak hanya obat, makanan dan kosmetik akan tetapi lebih luas dari itu menjangkau produk kimiawi, produk biologi, produk rekayasa genetik, serta barang gunaan yang dipakai, digunakan, atau dimanfaatkan oleh masyarakat. Pengaturannya pun menjangkau kehalalan produk dari hulu sampai hilir.

Proses Produk Halal (selanjutnya disebut PPH) didefinisikan sebagai rangkaian kegiatan untuk menjamin kehalalan produk mencakup penyediaan bahan, pengolahan, penyimpanan, pengemasan, pendistribusian, penjualan, dan penyajian Produk. Tujuan dari UUJPH adalah untuk menjamin setiap pemeluk agama beribadah dan menjalankan ajaran agamanya, memberikan pelindungan dan jaminan tentang kehalalan Produk yang dikonsumsi dan digunakan masyarakat sesuai dengan asas pelindungan, keadilan, kepastian hukum, akuntabilitas dan transparansi, efektivitas dan efisiensi, serta profesionalitas. Selain itu, penyelenggaraan sistem produk halal bertujuan memberikan kenyamanan, keamanan, keselamatan, dan kepastian ketersediaan Produk Halal bagi masyarakat dalam mengonsumsi dan menggunakan Produk, serta meningkatkan nilai tambah bagi Pelaku Usaha untuk memproduksi dan menjual Produk Halal. Jaminan produk halal secara teknis kemudian dijabatkan melalui proses sertifikasi. Sebelumnya sertifikasi halal bersifat voluntary (sukarela), dalam UUJPH menjadi mandatory (keharusan). Karena itu, semua produk yang masuk, beredar, dan diperdagangkan di wilayah Indonesia wajib bersertifikat halal. Hal inilah yang menjadi pembeda utama dengan produk perundang-undangan sebelumnya yang lebih dahulu terbit. Nantinya sebagai penanggung jawab sistem jaminan halal dilakukan oleh pemerintah yang diselenggarakan Menteri dengan membentuk Badan Penyelenggara JPH (BPJPH) yang berkedudukan di bawah dan bertanggung jawab kepada Menteri. ${ }^{6}$ Apabila diperlukan BPJPH dapat membentuk perwakilan di daerah.

Jaminan Produk Halal menjadi hal yang sangat penting mengingat kemajuan ilmu pengetahuan dan teknologi di bidang pangan, obat-obatan, dan kosmetik berkembang pesat. Hal ini berpengaruh secara nyata pada pergeseran pengolahan dan pemanfaataan bahan baku untuk makanan, minuman, kosmetik, obat-obatan, serta produk lainnya dari yang semula bersifat sederhana dan alamiah menjadi pengolahan dan pemanfaatan bahan baku hasil rekayasa ilmu pengetahuan. Pengolahan produk dengan pemanfaatan kemajuan ilmu pengetahuan dan teknologi memungkinkan percampuran antara yang halal dan yang haram baik yang disengaja maupun tidak disengaja. Oleh karena itu, untuk mengetahui kehalalan dan kesucian suatu Produk, diperlukan suatu kajian khusus yang membutuhkan pengetahuan multidisiplin, seperti pengetahuan dibidang pangan, kimia, biokimia, teknik industri, biologi, farmasi dan pemahaman tentang syariat Islam untuk

\footnotetext{
${ }^{6}$ Sebagai tindak lanjut dari UUJPH Presiden Joko Widodo mengeluarkan Peraturan Presiden (Perpres) No. 83 Tahun 2015 tentang Kementerian Agama di dalamnya menegaskan kedudukan Badan Penyelenggara Jaminan Produk Halal (BPJPH) yang mempunyai tugas melaksanakan penyelenggaraan jaminan produk halal sesuai dengan ketentuan peraturan perundang-undangan yang kedudukannya setingkat dengan Direktorat Jenderal.
} 
menentukan apakah makanan, minuman, kosmetik, obat-obatan serta produk lainnya layak diberikan sertifikasi halal atau tidak. ${ }^{7}$

Sertifikasi halal diberikan untuk produk-produk makanan yang dimana konsumen muslim dapat mengkonsumsinya dan sesuai dengan syariat islam. Sertifikasi halal berfungsi sebagai pedoman dan angan penting untuk mempertahankan hidup secara islami. Namun karena banyaknya jenis produk dan layanan yang berkembang diluar wilayah dunia islam, sulit untuk membedakan antara yang halal dan haram. Hal ini membuat setiap negara memiliki standar halal sendiri. ${ }^{8}$ Menurut ajaran Islam, makanan halal adalah makanan yang baik untuk di konsumsi. Sedangkan pengertian makanan yang baik untuk dikonsumsi adalah segala makanan yang dapat membawa kesehatan bagi tubuh, dapat menimbulkan nafsu makan dan tidak dilarang oleh agama maupun negara. ${ }^{9}$ Sebagai negara dengan penduduk mayoritas Muslim, menjaga nilai halal suatu produk, terutama makanan merupakan hal utama yang harus diprioritaskan. Dewasa ini masih banyak ditemukan peredaran produk makanan dan minuman baik yang lokal maupun yang import belum berlabel sertifikat halal atau sertifikat halal yang terdapat pada kemasan makanan dan minuman diragukan kebenarannya. Hal ini menunjukan masih rendahnya kewajiban pelaku usaha mengikuti ketentuan hukum sertifikat halal. ${ }^{10}$

Kehalalan suatu produk makanan khususnya "Samyang" sempat menjadi topik pembicaraan di masyarakat Indonesia khususnya para konsumen muslim yang mengkonsumsinya. Pada pertengahan Juni 2017, BPOM mengumumkan bahwa ada kandungan babi (tidak halal) pada empat produk mie instan asal Korea. Empat produk itu adalah Nongshim dengan nama produk Shin Ramyun Black, Ottogi dengan nama produk Yeul Ramen, dan dua varian produk Samyang, yakni Samyang Kimchi, dan Samyang UDong. Empat produk mie instan ini diimpor oleh PT Korinus. ${ }^{11}$ Samyang merupakan salah satu produk mie instan yang sangat populer sejak tahun 2016 lalu. Meski dua varian produknya tidak halal, namun ada varian produk lain dari Samyang yang telah memiliki sertifikasi halal, yaitu Samyang varian spicy hot chicken ramen dan hot chicken ramen chesee. Dua varian Samyang ini diimpor oleh PT Korinus. Produk Samyang sendiri sebenarnya memiliki nama asli Buldalk Bokkeummyeon. Namun, konsumen mie di Indonesia lebih mengenal produk ini dengan sebutan Samyang karena tulisan latin yang

\footnotetext{
${ }^{7}$ Syafrida dan Ralang Hartati, Kewajiban Sertifikat Halal Untuk Produk Import di Indonesia, SALAM; Jurnal Sosial \& Budaya, Syar-i FSH UIN Syarif Hidayatullah, Jakarta Vol. 6 No. 4 (2019), p.363-376.

${ }^{8}$ Association, K. H, "What is the meaning of "Halal"?", Korea Institute of Halal Industri, http://koreahalal.org/archives/23, Diakses pada 18 Maret 2020, Pukul 18.06 WIB.

${ }^{9}$ Panji Adam Agus Putra, "Kedudukan Sertifikasi Halal Dalam Sistem Hukum Nasional Sebagai Upaya Perlindungan Konsumen Dalam Hukum Islam", Jurnal Ekonomi dan Keuangan Syariah, Vol.1 No. 1, 2017, hlm. $150-165$.

${ }^{10}$ Asep Syarifuddin Hidayat dan Mustolih Siradj, "Sertifikasi Halal dan Sertifikasi Non-Halal pada Produk Pangan Industri”, Jurnal Ahkam, Vol. 15, No. 2, 2015, hlm. 199-200.

11 David Oliver Purba, "Tak Semua Samyang Yang Beredar di Indonesia Mengandung Babi”, http://megapolitan.kompas.com/read/2017/06/21/15452521/tak.semua.samyang.yang.beredar.di.indon esia.mengandung.babi. Diakses pada 10 Maret 2020, Pukul 19.00 WIB.
} 
bisa dibaca pada bungkus mie ini hanya "Samyang", sedangkan huruf lainnya merupakan huruf Korea. ${ }^{12}$

Di Indonesia, produk Samyang menjadi produk yang cukup laris dan sangat disukai oleh masyarakat. Hal ini dibuktikan dari keterangan salah satu marketplace terbesar di Indonesia, yakni Elevenia yang pernah mencatat transaksi jual-beli mie samyang yang mencapai 9.210 bungkus dalam sehari pada Oktober 2016 lalu. ${ }^{13}$ Walaupun produk Samyang telah laris di pasaran, BPOM menyatakan bahwa empat produk mie instan Korea yang diimport oleh PT Korinus mengandung babi (tidak halal. PT Korinus selaku importir Samyang dengan varian yang sudah memiliki 5 sertifikasi halal mengaku mengalami kerugian yang signifikan. Kerugian ini diduga sebagai akibat maraknya pemberitaan di berbagai media massa. Seperti yang dikatakan oleh Sales and Marketing Manager PT Korinus, Endra Nirwana bahwa sejak berita itu beredar hingga 21 Juni 2017 penjualannya sudah turun sekitar 30 persen. Meski demikian, Endra tidak bersedia mengungkapkan lebih jauh berapa jumlah kerugian dalam bentuk rupiah, dan juga jumlah penjualan mi Samyang PT Korinus per harinya. ${ }^{14}$

Di Indonesia, perlindungan makanan menjadi standar yang perlu dipenuhi. Hal ini karena produk makanan yang terdistribusi akan diserap oleh pasar yang mayoritas konsumennya adalah pemeluk agama atau keyakinan tertentu yang mewajibkan pemeluknya untuk mengkonsumsi makanan tertentu. Semisal umat muslim yang diwajibkan untuk mengkonsumsi produk makanan halal atau umat Buddha yang tidak boleh mengkonsumsi olahan sapi dan lain sebagainya. ${ }^{15}$ Oleh karena itu, informasi tentang kandungan produk makanan serta informasi kehalalan produk menjadi standard makanan sebelum didistribusikan ke masyarakat. Standard jaminan dalam makanan sepenuhnya ditanggung oleh produsen atau media perantara yang mendistribusikan produk tersebut. Hal ini sesuai dengan bunyi Pasal 41 Undang-Undang Nomor 18 Tahun 2012 Tentang Pangan (selanjutnya disebut dengan UU Pangan) yaitu: "Badan usaha yang memproduksi pangan olahan untuk diedarkan dan atau orang perorangan dalam badan usaha diberi tanggung jawab terhadap jalannya usaha tersebut bertanggung jawab atas keamanan pangan yang diproduksinya terhadap kesehatan orang lain yang mengkonsumsi makanan tersebut".

Pasal 1 Undang-Undang Nomor 8 Tahun 1999 tentang Perlindungan Konsumen (selanjutnya disebut dengan UUPK) menjelaskan bahwa "Perlindungan konsumen adalah

\footnotetext{
${ }^{12}$ Sri Handayani, "Waspadai Produk Impor Tidak Berlabel Halal", https://www.republika.co.id/berita/koran/dialog-jumat/16/03/11/o3vfwa23-waspadai-produk-importidak-berlabel-halal. Diakses pada 20 Maret 2020, Pukul 15.05 WIB.

${ }^{13}$ Christina Andhika Setyanti, "Dalam Sehari 9210 Bungkus Mi Samyang Terjual di Indonesia", https://www.cnnindonesia.com/gaya-hidup/20161015060604-262-165660/dalam- sehari-9210-bungkusmi-samyang-terjual-di-indonesia/. Diakses pada 10 Maret 2020, Pukul 18.06.

14 Tim Viva, "Importir Mi Samyang Siap Tempuh Jalur Hukum", http://www.viva.co.id/gayahidup/kuliner/928501-importir-mi-samyang-siap-tempuh-jalur-hukum. Diakses pada 20 Maret 2020, Pukul 21.59 WIB

${ }^{15}$ Burhanuddin, "Pemikiran Hukum Perlindungan Konsumen dan Sertifikasi Halal”, Malang: UIN-Maliki Press, 2011, hlm. 139-140.
} 
segala upaya yang menjamin adanya kepastian hukum untuk memberikan jaminan kepada konsumen". Oleh karena itu, konsumen berhak untuk mendapatkan informasi tentang kandungan produk, bahan yang dibuat serta kehalalan produk yang akan dikonsumsi. Disisi lain, meningkatnya kesadaran masyarakat terhadap produk halal, tidak diimbangi dengan tindakan para pelaku usaha dalam memberikan informasi produk yang tepat atau mensertifikatkan kehalalan produksinya dan memberikan label halal pada kemasannya. ${ }^{16}$ Kewajiban mencantumkan informasi makanan, seperti yang telah dijelaskan dalam Pasal 8 UUPK bahwa perbuatan yang dilarang bagi pelaku usaha dalam memproduksi dan atau memperdagangkan barang dan atau jasa adalah "tidak memasang label atau membuat penjelasan barang yang memuat nama barang, ukuran, berat/isi bersih atau netto, komposisi, aturan pakai, tanggal pembuatan, akibat sampingan, nama dan alamat pelaku usaha serta keterangan lain untuk penggunaan yang menurut ketentuan harus dipasang/dibuat".

Produsen yang memasarkan produknya tanpa penjelasan komposisi bisa berakibat fatal terhadap konsumen tertentu. Seperti dalam contoh kasus BPOM telah mengeluarkan surat edaran Nomor: IN.08.04.532.06.17.2432 bahwa mie instant impor yang berasal dari Korea yang disinyalir berbahan dasar babi dan dinilai meresahkan warga. Mie instant bernama Samyang, Nongshim dan Ottogi yang mengandung babi dalam komposisinya tersebar di supermarket di wilayah Indonesia, tentunya hal ini meresahkan konsumen muslim. Berdasarkan latar belakang diatas, penulis akan mengkaji pengaturan terkait dengan sertifikasi halal atas produk makanan dalam perspektif hukum perlindungan konsumen di Indonesia dan Korea dan bentuk perlindungan konsumen bagi konsumen muslim.

\section{PEMBAHASAN}

\section{Pengaturan tentang sertifikasi halal atas produk makanan dalam perspektif hukum perlindungan konsumen di Indonesia dan Korea}

Kehalalan suatu produk telah diatur dengan jelas dalam UUPK. Namun, pada kenyataannya UUPK hanya mengatur terkait dengan pelaku usaha yang dilarang memproduksi dan/atau memperdagangkan barang dan/atau jasa yang tidak mengikuti ketentuan berproduksi secara halal, sebagaimana pernyataan "halal" yang dicantumkan dalam label. Sedangkan, terkait dengan keharusan adanya keterangan halal dalam suatu produk diatur dalam Undang-Undang Nomor 33 Tahun 2014 tentang Jaminan Produk Halal (selanjutnya disebut UU Produk Halal). UU Produk Halal mendefinisikan bahwa "produk" adalah barang dan/atau jasa yang terkait dengan makanan, minuman, obat,

\footnotetext{
${ }^{16}$ N.H.T Siahaan, Hukum Perlindungan Konsumen dan Tanggung Jawab Produk, Jakarta: Panta rei, 2011, hlm 10.
} 
kosmetik, produk kimiawi, produk biologi, produk rekayasa genetik, serta barang gunaan yang dipakai, digunakan, atau dimanfaatkan oleh masyarakat. Sedangkan yang dimaksud dengan "produk halal" adalah produk yang telah dinyatakan halal sesuai dengan syariat Islam.

UU Produk Halal telah mengatur secara jelas bahwa produk yang masuk, beredar, dan diperdagangkan di wilayah Indonesia wajib bersertifikat halal. Jadi, pada dasarnya, jika produk yang dijual tersebut adalah produk halal, maka wajib bersertifikat halal. Pasal 25 UU Produk Halal mengatur tentang kewajiban pelaku usaha untuk mencantumkan label halal pada setiap produk yang hendak dijualnya. Kewajiban mencantumkan label halal oleh pelaku usaha yang telah mendapatkan sertifikat halal, perlu diketahui bahwa bentuk label halal ini ditetapkan oleh Badan Penyelenggara Jaminan Produk Halal (selanjutnya disebut dengan BPJPH) dan berlaku nasional. ${ }^{17}$ Dalam perkembangannya, telah diundangkan pada tanggal 3 Mei 2019 peraturan pelaksana dari UU Produk Halal yaitu Peraturan Pemerintah Nomor 31 Tahun 2019 tentang Peraturan Pelaksanaan Undang-Undang Nomor 33 Tahun 2014 tentang Jaminan Produk Halal (selanjutnya disebut dengan PP 31/2019). ${ }^{18}$

Pengawasan jaminan produk halal juga dilakukan terhadap pencantuman keterangan tidak halal. Pengawasan pencantuman keterangan tidak halal yang dapat berupa gambar, tanda, dan/atau tulisan dilakukan terhadap produk. Yang dimaksud dengan "tulisan" adalah pembedaan warna tulisan dalam komposisi produk. ( Pasal 78 ayat (1), ayat (2) dan Penjelasan Pasal 78 ayat (2) PP 31/2019.) Ketentuan mengenai gambar, tanda, dan/atau tulisan tersebut harus mencakup pelindungan dan hak asasi manusia terhadap kelompok rentan, khususnya penyandang disabilitas, antara lain berupa menjamin pemenuhan hak penyandang disabilitas dalam kemudahan mendapatkan informasi kehalalan produk yang disesuaikan dengan kemampuan penyandang disabilitas yang bersangkutan. Sebagai contoh yaitu tersedianya gambar, tanda, dan/atau tulisan dalam huruf braille bagi penyandang disabilitas yang mengalami masalah dalam penglihatan.

Badan Pengawas Obat dan Makanan (selanjutnya disebut BPOM) menemukan produk mie terkenal asal Korea positif mengandung babi. Hal tersebut diketahui setelah BPOM melakukan pengambilan sampel dan pengujian terhadap beberapa mie instan asal Korea salah satunya adalah mie samyang. Dari beberapa produk yang diuji oleh BPOM, terdapat empat produk mi instan positif terdeteksi mengandung DNA babi. Di negara asal mi Samyang tersebut, cukup sulit untuk membedakan produk halal dan tidak halal karna tidak terdapat logo halal dalam setiap produk makanan yang di pasarkannya. Memisahkan antara produk halal dan tidak halal bukanlah menjadi fokus dalam program pemerintah setempat. Hal tersebut terjadi karena Korea bukanlah negara yang berpenduduk mayoritas

\footnotetext{
${ }^{17}$ Ahda Segati, "Pengaruh Persepsi Sertifikasi Halal, Kualitas Produk, dan Harga terhadap Persepsi Peningkatan Penjualan", Jurnal Ekonomi dan Bisnis Islam, Vol. 3, No. 2, 2018, hlm. 167.

${ }^{18}$ LPPOM-MUI, Panduan Umum Sistem Jaminan Halal LPPOM-MUI, Bandung: LPPOMMUI, Edisi IV, 2011, hlm. 9.
} 
Muslim seperti Indonesia, sehingga tidak ada ketegasan pada produk terkait Halal dan tak Halal. ${ }^{19}$

Penduduk Muslim di Korea hanya sekitar 150.000 - 200.000 penduduk atau di bawah $0,5 \%$ dari total penduduk Korea yang totalnya mencapai 50 juta penduduk. Mayoritas penduduk Korea beragama Kristen yang dalam ajaran agamanya memperbolehkan untuk mengonsumsi daging babi. Namun, melihat perkembangan pasar produk Halal yang mulai meningkat serta proyeksi bahwa pasar makanan Halal global pada 2019 akan mencapai 21,2\% dan meningkatnya wisatawan Muslim yang mengunjungi negara tersebut, Korea mulai melirik pasar produk halal.

Agar dapat mengekspor produk ke negara Muslim, maka dibutuhkan sertifikat halal. Korea pun mulai memberi label halal pada produk-produk mereka. Label halal juga mulai menghiasi restoran-restoran di Korea sebagai salah satu cara untuk terus menarik minat wisatawan Muslim. Awalnya, Korea menentukan lembaga yang ertanggung jawab dalam memberi label halal atau sertifikasi Halal. Jika di Indonesia ada Majelis Ulama Indonesia (selanjutnnya disebut MUI) maka di Korea ada Korean Muslim Federation (selanjutnya disebut KMF).

KMF adalah satu satunya lembaga resmi di Korea Selatan yang mempunyai otoritas untuk mengeluarkan sertifikat halal bagi produk-produk makanan halal, restoran maupun hotel yang ada di Korea Selatan. KMF memiliki misi utama yaitu untuk fokus terhadap peningkatan kualitas hidup masyarakat muslim di Korea Selatan seperti memperkuat program pendidikan dasar, pembentukan pemakaman komunitas muslim, dan promosi pendirian Universitas Islam di Korea. ${ }^{20} \mathrm{KMF}$ merupakan lembaga yang berperan penting dalam pengembangan industri halal food di Korea Selatan, popularitas halal food yang sedang "booming" di Korea terkait kecintaan masyarakat muslim terhadap makanan Korea Selatan membuat Korea Selatan ingin memanfaatkan kesempatan tersebut untuk memasuki pasar halal global karena industri tersebut memiliki potensi yang sangat besar terhadap peningkatan perekonomian negara. Oleh sebab itu, pemerintah Korea selatan berupaya untuk mengadakan kerjasama antara KMF dengan Korea Food Research Institute. Hasil dari kerjasama tersebut akan menghasilkan sertifikat halal untuk makanan Korea yang memenuhi standarisari halal. ${ }^{21}$

Sayangnya, meski pemerintah Korea sudah mulai melirik produk Halal tetapi regulasi dan penegakan hukum yang berkaitan dengan produk Halal masih sangat minim. Oleh karena itu, di Korea Legislation Research Institute (selanjutnya disebut KLRI) yang merupakan lembaga pembuat pengaturan perdagangan Korea disebutkan: "Acceptance of agency for commercial transactions" 22 yang berarti: Korea memberikan kebebasan kepada setiap agen untuk melakukan transaksi perdagangan termasuk dengan pemberian

\footnotetext{
19 Zulham, Peran Negara dalam Perlindungan Konsumen Muslim Terhadap Produk Halal, Jakarta: Kencana, 2018, hlm 69.

${ }^{20}$ Ricky Ardiansyah, Strategi Pemerintah Korea Selatan Dalam Mempromosikan Halal Food Terhadap Indonesia, Skripsi, Semarang: Fakultas Hukum Universitas Diponegoro, 2018, hlm. 147-158.

${ }^{21}$ Ibid.

22 Ibid.
} 
label halal pada produknya. Hingga saat ini, label Halal di Korea Selatan masih penuh masalah. Hal itu disebabkan karena pemberi layanan label Halal tidak hanya KMF tetapi ada juga perusahaan swasta lainnya. Banyak restoran atau produk makanan yang mulai diberi label halal, tetapi dipalsukan. Polisi-polisi Korea tak jarang menangkap perusahaan yang kedapatan menjual makanan dengan logo Halal palsu. Sayangnya, perusahaanperusahaan tersebut akan dengan mudah kembali membuka bisnisnya dengan kembali menjual makanan dengan logo Halal palsu karena masih minimnya regulasi mengenai produk Halal di Korea. ${ }^{23}$

Ada begitu banyak asosiasi terkait Islam yang diselenggarakan oleh penjual produk berlogo Halal namun palsu dengan memanfaatkan ketidaksempurnaan hukum Korea mengenai produk Halal. Mereka membuat asosiasi, memberi tanda atau label Halal pada produk mereka sendiri, jika tertangkap polisi, mereka nantinya hanya akan mengganti nama asosiasi mereka dan kembali melakukan bisnis yang sama. Ini menjadi tantangan besar bagi pemerintah Korea. Saat ini pemerintah Korea tengah berupaya untuk memperkenalkan KMF sebagai lembaga sertifikasi produk Halal di Korea. Malaysia dan Singapura adalah dua negara yang sudah mengakui produk makanan Korea yang berlabel Halal dari KMF. Sedangkan untuk Indonesia sendiri, pemerintah Korea tengah berusaha untuk memulai negosiasi soal sertifikasi halal lokal agar produknya dapat diterima di negara-negara mayoritas Muslim seperti Indonesia, menurut salah seorang pejabat Kementerian Pertanian Korea Selatan. Sebelum tercapai kesepakatan, kasus mi Samyang mengandung babi ini menyeruak sehingga membuat kaum Muslim untuk sementara tidak mengkonsumsimnya. Pemerintah Korea pun harus bekerja lebih keras lagi jika memang ingin masuk dalam pasar produk Halal di negara mayoritas Muslim, termasuk di Indonesia.

Jadi, berdasarkan uraian di atas, dapat ditarik kesimpulan bahwa label halal pada produk pangan wajib dicantumkan oleh setiap pelaku usaha untuk mewujudkan suatu kepercayaan (trust), kepuasan, dan loyalitas bagi konsumen muslim bahwa produk yang dijual oleh pelaku usaha layak untuk konsumsi tanpa melanggar syariat islam. Regulasi dan penegakan hukum yang berkaitan dengan produk Halal masih sangat minim. Oleh karena itu, dalam pengaturan perdagangan Korea disebutkan bahwa: "Acceptance of agency for commercial transactions" 24 yang berarti: Korea memberikan kebebasan kepada setiap agen untuk melakukan transaksi perdagangan termasuk dengan pemberian label halal pada produknya. Hingga saat ini, label Halal di Korea Selatan masih penuh masalah. Hal itu disebabkan karena pemberi layanan label Halal tidak hanya KMF tetapi ada juga perusahaan swasta lainnya. Banyak restoran atau produk makanan yang mulai diberi label halal, tetapi dipalsukan. Oleh sebab itu, pemerintah Korea selatan berupaya untuk mengadakan kerjasama antara KMF dengan Korea Food Research Institute. Hasil dari kerjasama tersebut akan menghasilkan sertifikat halal untuk makanan Korea yang

\footnotetext{
${ }^{23}$ Edy Supaino dan Martin Roestamy, "Kepastian Hukum Tentang Penggunaan Label Halal Guna Memberikan Perlindungan Kepada Konsumen Muslim”, Jurnal Living Law, Vol. 9, No. 1, 2017, hlm.58. ${ }^{24}$ Ibid.
} 
memenuhi standarisari halal. Sedangkan untuk Indonesia sendiri, pemerintah Korea tengah berusaha untuk memulai negosiasi soal sertifikasi halal lokal agar produknya dapat diterima di negara-negara mayoritas Muslim seperti Indonesia.

\section{Bentuk perlindungan konsumen bagi konsumen muslim}

Perlindungan konsumen adalah segala upaya yang menjamin adanya kepastian hukum untuk memberi perlindungan kepada konsumen yang memakai barang dan/atau jasa yang tersedia dalam masyarakat, baik bagi kepentingan diri sendiri, keluarga, orang lain maupun makhluk hidup lain dan tidak untuk diperdagangkan. Asas-asas perlindungan konsumen, diantaranya: Asas manfaat; Asas keadilan; Asas Keseimbangan; Asas keamanan dan keselamatan konsumen; dan Asas kepastian hukum. Adapun tujuan yang hendak dicapai dalam hal perlindungan konsumen, diantaranya: meningkatkan kesadaran, kemampuan dan kemandirian konsumen untuk melindungi diri; mengangkat harkat dan martabat konsumen dengan cara menghindarkannya dari efek negatif pemakaian barang dan/atau jasa; meningkatkan pemberdayaan konsumen dalam memilih, menentukan dan menuntut hak-haknya sebagai konsumen; menciptakan sistem perlindungan konsumen yang mengandung unsur kepastian hukum dan keterbukaan informasi serta akses untuk mendapatkan informasi; menumbuhkan kesadaran pelaku usaha mengenai pentingnya perlindungan konsumen sehingga tumbuh sikap yang jujur dan bertanggung jawab dalam berusaha; meningkatkan kualitas barang dan/atau jasa yang menjamin kelangsungan usaha produksi barang dan/atau jasa, kesehatan, keamanan, kenyamanan, dan keselamatan konsumen.

Selain dilindungi oleh Undang-undang, konsumen juga diberikan hak atas kenyamanan, keamanan dan keselamatan dalam mengkonsumsi barang dan/atau jasa. Sertifikasi halal merupakan suatu langkah dalam perlindungan konsumen karena didasari oleh kenyataan bahwa banyak negara-negara yang berpenduduk mayoritas beragama muslim. ${ }^{25}$ Sertifikasi halal juga menjadi salah satu faktor penting dalam menawarkan produk dan jasa, apalagi bagi negara-negara yang bergabung dalam pasar bebas masyarakat ekonomi ASEAN. Salah satu tujuan pasar bebas masyarakat ekonomi ASEAN adalah untuk memberikan kelayakan produk untuk di konsumsi yang berarti tidak bertentangan dengan aturan agama yang dianutnya. Konsumen berhak mendapatkan informasi yang benar, jelas, dan jujur atas kondisi barang dan/atau jasa. Hal ini berarti keterangan halal yang diberikan oleh perusahaan haruslah benar atau telah teruji terlebih dahulu melalui pengujian kehalalan yang telah ditentukan. ${ }^{26}$ Oleh karena itu, konsumen perlu mendapatkan sebuah kepastian hukum bahwa produk yang digunakan tidak mengandung sesuatu yang tidak halal dan juga diproduksi secara halal. Adanya sertifikasi serta labelisasi halal bukan saja bertujuan memberi ketentraman batin pada umat muslim tetapi juga ketenangan berproduksi bagi produsen. Untuk menghadapi globalisasi

\footnotetext{
${ }^{25}$ Happy Susanto, Hak-hak Konsumen Jika Dirugikan, Jakarta: Visi Media, 2010, hlm.23.

${ }^{26}$ May Lim Charity, "Jaminan Produk Halal di Indonesia”, Jurnal Legislasi Indonesia, Vol. 14, No. 01, 2017, hlm. 100.
} 
ekonomi yang semakin nyata, maka sertifikasi dan labelisasi halal semakin diperlukan untuk melindungi konsumen Muslim. ${ }^{27}$

Industri halal telah menjadi trend tersendiri dalam masyarakat dunia, bukan hanya dari kalangan Muslim tetapi berbagai penganut agama lain. Dalam menghadapi Masyarakat Ekonomi ASEAN (selanjutnya disebut MEA), industri halal Indonesia memiliki peluang besar untuk dapat bersaing dengan negara lain dalam menyalurkan produk bersertifikasi halal di kawasan ASEAN. Sayangnya, dari seluruh produsen di Indonesia baru sedikit yang memiliki kesadaran akan pentingnya sertifikasi halal. Hal ini dikarenakan prosedur yang rumit serta biaya yang besar membuat para produsen enggan untuk mendaftarkan industri mereka agar memiliki sertifikat halal. Minimnya sumber daya manusia dan infrastuktur memadai juga berpengaruh terhadap minat pendaftaran sertifikasi halal oleh pelaku usaha seperti para ahli di bidang auditor halal dan produk halal. ${ }^{28}$ Oleh karena itu, dibutuhkan dukungan dari pemerintah berupa penyediaan infrastruktur, seperti labolatorium, peralatan skrining, dan peralatan untuk menganalisa kehalalan suatu produk. Apabila hal tersebut sudah terealisasi, maka tujuan pemerintah untuk mewujudkan kemudahan dalam sertifikasi halal tanpa mengurangi kualitas dari

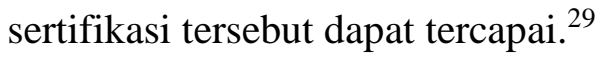

Sebagai contoh, di Indonesia yang mayoritas penduduknya muslim, seharusnya lebih siap memberikan label halal pada semua sektor yang akan diperjual belikan. Terutama kepastian halal pada produk makanan karena akan sangat mendukung kesuksesan pasar kuliner Indonesia. Namun, pada kenyataannya banyak pengusaha yang belum mendaftarkan produk mereka untuk mendapatkan sertifikat halal. Padahal, dengan adanya pencantuman label halal, konsumen lebih merasa aman dalam mengkonsumsi produk tersebut. Konsumen mendapatkan jaminan bahwa produk tersebut tidak mengandung sesuatu yang tidak halal dan diproduksi dengan cara yang halal dan beretika. Sedangkan bagi produsen, pencantuman label halal dapat membangun kepercayaan, kepuasan dan loyalitas konsumen terhadap produk tersebut. Produk yang bersertifikat halal memiliki keunggulan kompetitif dibandingkan dengan produk yang tidak mencantumkan label tersebut. ${ }^{30}$

Penentuan status halal atau haramnya sebuah produk baik makanan, obat-obatan atau kosmetik bukanlah perkara mudah. Asal usul bahan bisa melalui jalur yang berliku, bahkan dalam beberapa kasus sulit untuk ditentukan asal bahannya dan pemahaman

27 Petrus Teguh Kurniawan, Hubungan Persepsi Konsumen tentang Kehalalan Produk Samyang dan Terpaan Persuasi Reference Group terhadap Minat Beli Produk Samyang, Skripsi, Semarang: Universitas Diponegoro, 2017, hlm 84.

28 Yusuf Shofie, Perlindungan Konsumen dan Instrumen-instrumen Hukumnya, Bandung: Citra Aditya Bakti, 2009, hlm 43.

29 Tarsisius Murwadji, Teguh Tresna Puja Asmara, Intan Magdalena, "Empowerment of Micro Small Enterprises by Improving Halal Certified Food Products Through Corporate Social Responsibility", Jurnal Hukum Bisnis dan Investasi, Vol. 11 Nomor 2, 2020, hlm. 001 - 015

${ }^{30}$ Uun Faizah, Tinjauan Hukum Islam Terhadap Perlindungan Konsumen dalam jual beli makanan kemasan, Skripsi, Yogyakarta: Fakultas Syariah dan Hukum UIN Sunan Kalijaga, 2015, hlm 54. 
mengenai kehalalan produk itu sendiri. ${ }^{31}$ Perlindungan konsumen merupakan hak warga negara yang pada sisi lain merupakan kewajiban negara untuk melindungi warga negaranya khususnya atas produk yang halal dan baik. ${ }^{32}$ Setiap konsumen yang dirugikan dapat menggugat pelaku usaha melalui lembaga yang bertugas menyelesaikan sengketa antara konsumen dan pelaku usaha atau melalui peradilan yang berada di lingkungan peradilan umum. Begitu juga apabila terdapat penyalahgunaan label halal, konsumen dapat melakukan upaya hukum melalui dua cara, yaitu penyelesaian sengketa melalui pengadilan (litigasi) maupun penyelesaian sengketa diluar pengadilan (non litigasi). ${ }^{33}$

Dari pernyataan diatas, dapat ditarik kesimpulan bahwa sertifikasi halal merupakan salah satu bentuk perlindungan kosumen bagi konsumen muslim. Dengan adanya sertifikasi halal, keuntungan yang didapat oleh konsumen adalah kepastian akan kehalalan suatu produk pangan, obatan-obatan, maupun kosmetik sehingga dapat memberikan keamanan dan kenyamanan bagi konsumen ketika akan memakai produk tersebut. Selain itu, konsumen mendapat kepastian hukum dan perlindungan hukum. Sedangkan bagi produsen, dengan adanya sertifikasi halal atas produk mereka, akan meningkatkan kepercayaan dan kepuasan konsumen atas produk yang diperdagangkan sehingga citra dan daya saing perusahaan akan meningkat. Sertifikasi halal juga sebagai bentuk pertanggungjawaban produsen terhadap konsumen bahwa produk yang diperjual belikan merupakan produk yang layak untuk dikonsumsi menurut syariat Islam.

\section{PENUTUP}

Label halal pada produk pangan wajib dicantumkan oleh setiap pelaku usaha untuk mewujudkan suatu kepercayaan (trust), kepuasan, dan loyalitas bagi konsumen muslim bahwa produk yang dijual oleh pelaku usaha layak untuk konsumsi tanpa melanggar syariat islam. Regulasi dan penegakan hukum yang berkaitan dengan produk Halal masih sangat minim. Oleh karena itu, dalam pengaturan perdagangan Korea disebutkan bahwa: "Acceptance of agency for commercial transactions" yang berarti: Korea memberikan kebebasan kepada setiap agen untuk melakukan transaksi perdagangan termasuk dengan pemberian label halal pada produknya. Hingga saat ini, label Halal di Korea Selatan masih penuh masalah. Hal itu disebabkan karena pemberi layanan label Halal tidak hanya KMF tetapi ada juga perusahaan swasta lainnya. Banyak restoran atau produk makanan yang mulai diberi label halal, tetapi dipalsukan. Oleh sebab itu, pemerintah Korea selatan berupaya untuk mengadakan kerjasama antara KMF dengan Korea Food Research Institute. Hasil dari kerjasama tersebut akan menghasilkan sertifikat halal untuk makanan Korea yang memenuhi standarisari halal. Sedangkan untuk Indonesia sendiri, pemerintah Korea tengah berusaha untuk memulai negosiasi soal sertifikasi halal lokal agar produknya dapat diterima di negara-negara mayoritas Muslim seperti Indonesia.

\footnotetext{
${ }^{31}$ Anonim, Panduan Umum Sistem Jaminan Halal, LPPOM-MUI.Bandung: LPPOM-MUI, 2018, hlm 31.

${ }^{32}$ Abdurrahman Konoras, Jaminan Produk Halal di Indonesia Prespektif Hukum Perlindungan Konsumen, Depok: Rajawali Press, 2017, p. 60.

${ }^{33}$ Shidarta, Hukum Perlindungan Konsumen Indonesia, Jakarta: Gramedia Widiasarana Indonesia, 2016, hlm 60
} 
Sertifikasi halal merupakan salah satu bentuk perlindungan kosumen bagi konsumen muslim. Dengan adanya sertifikasi halal, keuntungan yang didapat oleh konsumen adalah kepastian akan kehalalan suatu produk pangan, obatan-obatan, maupun kosmetik sehingga dapat memberikan keamanan dan kenyamanan bagi konsumen ketika akan memakai produk tersebut. Selain itu, konsumen mendapat kepastian hukum dan perlindungan hukum. Sedangkan bagi produsen, dengan adanya sertifikasi halal atas produk mereka, akan meningkatkan kepercayaan dan kepuasan konsumen atas produk yang diperdagangkan sehingga citra dan daya saing perusahaan akan meningkat. Sertifikasi halal juga sebagai bentuk pertanggungjawaban produsen terhadap konsumen bahwa produk yang diperjual belikan merupakan produk yang layak untuk dikonsumsi menurut syariat Islam.

Untuk itu disarankan bagi Konsumen Muslim agar lebih teliti lagi dalam memilih produk makanan yang halal dengan memperhatikan logo/label halal pada kemasan makanan dan memperhatikan kandungan/ingredients bahan-bahan dalam suatu produk makanan apakah layak di konsumsi atau tidak berdasarkan syariat Islam. Lebih lanjut, pemerintah harus lebih teliti lagi dalam menyortir produk makanan import yang akan di perjualbelikan di Negara Indonesia dengan memastikan bahwa produk import tersebut telah memiliki sertifikasi halal dari Negara asalnya. Terakhir bagi pemerintah Korea perlu menjamin kehalalan suatu produk yang akan di export dengan cara mencantumkan logo/label halal pada setiap kemasan makanan ketika akan mendistribusikan produk tersebut ke berbagai Negara yang mayoritas berpenduduk muslim di dunia

\section{DAFTAR PUSTAKA}

\section{Buku}

Abdurrahman Konoras, "Jaminan Produk Halal di Indonesia Prespektif Hukum Perlindungan Konsumen”, Depok: Rajawali Press, 2017.

Anonim, Kamus Bahasa Indonesia, Departemen Pendidikan Nasional, Jakarta: Pusat Bahasa, 2018.

Anonim, Panduan Umum Sistem Jaminan Halal, LPPOM-MUI.Bandung: LPPOM-MUI, 2018.

Burhanuddin, "Pemikiran Hukum Perlindungan Konsumen dan Sertifikasi Halal", Malang: UIN-Maliki Press, 2011.

LPPOM-MUI, Panduan Umum Sistem Jaminan Halal LPPOM-MUI, Bandung: LPPOMMUI, Edisi IV, 2011.

Happy Susanto, Hak-hak Konsumen Jika Dirugikan, Jakarta: Visi Media, 2010.

N.H.T Siahaan, Hukum Perlindungan Konsumen dan Tanggung Jawab Produk, Jakarta: Panta rei, 2011.

Shidarta, Hukum Perlindungan Konsumen Indonesia, Jakarta: PT. Gramedia Widiasarana Indonesia, 2016.

Yusuf Shofie, Perlindungan Konsumen dan Instrumen-instrumen Hukumnya, Bandung: PT. Citra Aditya Bakti, 2009. 
Dialogia luridica: Jurnal Hukum Bisnis dan Investasi

Volume 12 Nomor 1, November 2020

Zulham, Peran Negara dalam Perlindungan Konsumen Muslim Terhadap Produk Halal, Jakarta: Kencana, 2018.

\section{Jurnal}

Ahda Segati, "Pengaruh Persepsi Sertifikasi Halal, Kualitas Produk, dan Harga terhadap Persepsi Peningkatan Penjualan”, Jurnal Ekonomi dan Bisnis Islam, Vol. 3, No. 2, 2018.

Asep Syarifuddin Hidayat and Mustolih Siradj, "Sertifikasi Halal dan Sertifikasi NonHalal pada Produk Pangan Industri”, Jurnal Ahkam, Vol. 15, No. 2, 2015.

Edy Supaino dan Martin Roestamy, "Kepastian Hukum Tentang Penggunaan Label Halal Guna Memberikan Perlindungan Kepada Konsumen Muslim”, Jurnal Living Law, Vol. 9, No. 1, 2017.

May Lim Charity, "Jaminan Produk Halal di Indonesia”, Jurnal Legislasi Indonesia, Vol. 14, No. 01, 2017.

Musyfikah Ilyas, "Sertifikasi dan Labelisasi Produk Halal Prespektif Maslahat", Jurnal Al-Qadau, Vol. 4, No. 2, 2017.

Panji Adam Agus Putra, "Kedudukan Sertifikasi Halal Dalam Sistem Hukum Nasional Sebagai Upaya Perlindungan Konsumen Dalam Hukum Islam”, Jurnal Ekonomi dan Keuangan Syariah, Vol.1 No. 1, 2017.

Tarsisius Murwadji, Teguh Tresna Puja Asmara, Intan Magdalena, "Empowerment of Micro Small Enterprises by Improving Halal Certified Food Products Through Corporate Social Responsibility”, Jurnal Hukum Bisnis dan Investasi, Vol. 11 Nomor 2, 2020.

Sjarif Hasan, "Pemerintah Dorong Sertifikasi Halal UKM", Jurnal Halal, Vol. 1, No. 91, 2011.

Syafrida, "Sertifikasi Halal pada Produk Makanan dan Minuman Memberi Perlindungan dan Kepastian Hukum Hak-Hak Konsumen Muslim”, Jurnal Hukum, Vol. 7 No. 2, 2016.

Syafrida dan Ralang Hartati, Kewajiban Sertifikat Halal Untuk Produk Import di Indonesia, SALAM; Jurnal Sosial \& Budaya, Syar-i FSH UIN Syarif Hidayatullah, Jakarta Vol. 6 No. 4, 2019

\section{Skripsi}

Ricky Ardiansyah, Strategi Pemerintah Korea Selatan Dalam Mempromosikan Halal Food Terhadap Indonesia, Skripsi, Semarang: Fakultas Hukum Universitas Diponegoro, 2018.

Petrus Teguh Kurniawan, Hubungan Persepsi Konsumen tentang Kehalalan Produk Samyang dan Terpaan Persuasi Reference Group terhadap Minat Beli Produk Samyang, Skripsi, Semarang: Universitas Diponegoro, 2017. 
Dialogia luridica: Jurnal Hukum Bisnis dan Investasi

Volume 12 Nomor 1, November 2020

Uun Fauziah, Tinjauan Hukum Islam Terhadap Perlindungan Konsumen dalam jual beli makanan kemasan, Skripsi, Yogyakarta: Fakultas Syariah dan Hukum UIN Sunan Kalijaga, 2015.

\section{Peraturan Perundang-undangan}

Undang-Undang Nomor 8 Tahun 1999 Tentang Perlindungan Konsumen

Undang-Undang Nomor 18 Tahun 2012 Tentang Pangan

Undang-Undang Nomor 33 Tahun 2014 tentang Jaminan Produk Halal

Peraturan Pemerintah Nomor 69 Tahun 1999 tentang Label dan Iklan Pangan

Peraturan Pemerintah Nomor 28 Tahun 2004 tentang Keamanan, Mutu dan Gizi Pangan

Peraturan Pemerintah Nomor 31 Tahun 2019 tentang Peraturan Pelaksanaan UndangUndang Nomor 33 Tahun 2014 tentang Jaminan Produk Halal

\section{Pranala Luar}

Association, K. H, “What is the meaning of "Halal”?”, Korea Institute of Halal Industri, http://koreahalal.org/archives/23.

Christina Andhika Setyanti, "Dalam Sehari 9210 Bungkus Mi Samyang Terjual di Indonesia", $\quad$ https://www.cnnindonesia.com/gaya-hidup/20161015060604-262165660/dalam-sehari-9210-bungkus-mi-samyang-terjual-di-indonesia/.

David Oliver Purba, "Tak Semua Samyang Yang Beredar di Indonesia Mengandung Babi”,

http://megapolitan.kompas.com/read/2017/06/21/15452521/tak.semua.samyang.y ang.beredar.di.indonesia.mengandung.babi.

Rudy Kurniawansyah, "Presentase Kaum Muslim di Indonesia Alami Penurunan", https://mediaindonesia.com/read/detail/59042-kaum-muslim-di-indonesiatinggal-70-persen.

Sri Handayani, "Waspadai Produk Impor Tidak Berlabel Halal", https://www.republika.co.id/berita/koran/dialog-jumat/16/03/11/o3vfwa23waspadai-produk-impor-tidak-berlabel-halal.

Tim Viva, "Importir Mi Samyang Siap Tempuh Jalur Hukum", http://www.viva.co.id/gaya_ $\quad$ hidup/kuliner/928501-importir-mi-samyang-siaptempuh-jalur-hukum. 